\title{
Impact of In Situ Soil in Soil-Bentonite Cutoff Wall Backfill on Compressibility and Hydraulic Conductivity
}

\author{
Ridong Fan $\mathbb{D},{ }^{1,2}$ Yuling Yang $\mathbb{D}{ }^{2}$ and Songyu Liu $\mathbb{D}^{2}$ \\ ${ }^{1}$ College of Environmental Science and Engineering, Donghua University, Shanghai 201620, China \\ ${ }^{2}$ Institute of Geotechnical Engineering, Southeast University, \\ Jiangsu Key Laboratory of Urban Underground Engineering \& Environmental Safety (Southeast University), \\ Nanjing 210096, China \\ Correspondence should be addressed to Ridong Fan; fanrd@dhu.edu.cn
}

Received 6 November 2019; Revised 9 December 2020; Accepted 28 December 2020; Published 20 January 2021

Academic Editor: Guang-Liang Feng

Copyright (๑ 2021 Ridong Fan et al. This is an open access article distributed under the Creative Commons Attribution License, which permits unrestricted use, distribution, and reproduction in any medium, provided the original work is properly cited.

\begin{abstract}
Soil-bentonite cutoff walls, consisting of excavated in situ soil and bentonite as backfills, are used extensively as vertical barriers for groundwater pollution control. Sand mixed with high-quality natural sodium bentonite $(\mathrm{NaB})$ is commonly used as a research object to investigate the hydraulic and compression properties of soil-bentonite backfills. However, pure sand could rarely be found in real conditions, and natural $\mathrm{NaB}$ may not be available readily in some countries such as China, India, and Turkey. This paper presents a comprehensive laboratory investigation on the compressibility and hydraulic conductivity $(k)$ of soil-bentonite backfills created by simulated in situ soil and low-quality sodium activated calcium bentonite (SACaB). The simulated in situ soils are prepared using sand-natural clay mixtures with sand to natural clay mass ratios ranging from 0.5 to 6.0 , and the bentonite content $(B C)$ in the base mixture ranges from 0 to $15 \%$. The result indicates that $B C$ dominates the compression index $\left(C_{c}\right)$ of the backfill, and a unique relationship between void ratio at effective vertical compression stress of $1 \mathrm{kPa}$ and compression index is proposed for various types of soil-bentonite backfills. An increase in either $B C$ or clay size fraction $(C F)$ in simulated in situ contributes to reducing $k$, but the impact of $C F$ in simulated in situ soil on $k$ tends to be insignificant for backfill with $B C$ higher than $6 \%$. A new characteristic parameter based on the concept of void ratio of bentonite $\left(e_{b}\right)$, named apparent void ratio of clay size fraction $\left(e_{C}\right)$, is developed for predicting soil-bentonite backfills created by in situ soils and bentonites with various contents.
\end{abstract}

\section{Introduction}

Contaminated sites resulting from industrial development and low-level waste disposal are becoming increasingly pressing global problems, especially in developing countries like China and India $[1,2]$. The soil-bentonite cutoff walls, consisting of excavated in situ soil, bentonite, and amendment with high sorption capacity as backfills, are used extensively to control the migration of contaminants in groundwater in both interim and permanent remedial actions in the United States, Canada, Japan, and China.

Sand mixed with high-quality bentonite (e.g., commercial sodium bentonites and polymer-bentonite composites) as backfill is commonly used as a research object to investigate the engineering properties, such as compressibility, permeability, chemical compatibility, and Earth pressures distribution, of soil-bentonite backfills [3-8]. Recently, clayey soil-low-quality calcium bentonite $(\mathrm{CaB})$ mixtures have been considered as an alternative as backfill when high-quality natural sodium bentonite $(\mathrm{NaB})$ is scarce, but $\mathrm{CaB}$ is abundant [9]. In addition, it is reported that the hydraulic conductivity of soil-bentonite backfill is significantly affected by the type of bentonite. The hydraulic conductivity of sand-bentonite backfill using low-quality $\mathrm{CaB}$ is unlikely to meet the typical regulatory limit of $10^{-9} \mathrm{~m} /$ $s$ even when the bentonite content is increased to $15 \%$ [1]. On the other hand, an approximate $5 \%$ of natural $\mathrm{NaB}$ in the backfill leads to yielding lower hydraulic conductivity value than $10^{-9} \mathrm{~m} / \mathrm{s}$ [4-6]. 
It should be noticed that although either clean sand or pure clay could rarely be found in real conditions, clean sand-bentonite backfills are generally used to investigate the performance of the soil-bentonite cutoff wall. To date, very few studies have systematically investigated the influence of in situ soil on the compressibility and hydraulic conductivity of soil-bentonite backfills. Limited studies show that simulating in situ soil with medium (42\%) to high (78\%) fines content mixed with bentonite-water slurry can be used as backfill for the slurry-trench cutoff wall without amending bentonite in the base mixture [10]. However, the impact of in situ soil (e.g., fines fraction and/or clayey-sized fraction) on compressibility and hydraulic conductivity has not been evaluated quantitatively.

In this study, two types of model soil-bentonite backfills were used to understand the impact of in situ soil on the compressibility and hydraulic conductivity $(k)$. The backfills included (1) sand-bentonite backfills with various percentages of bentonite (denoted as SBB) and (2) sand-claybentonite backfills with various percentages of natural clay and bentonite (denoted as SCBB). In addition, universal correlation equations were established using void ratio at $\sigma_{v}^{\prime}$ $=1 \mathrm{kPa}\left(e_{1}\right)$ and newly proposed apparent void ratio of clay size fraction $\left(e_{C}\right)$ to predict compression index $\left(C_{c}\right)$ and $k$ of soil-bentonite backfills containing various in situ soil and bentonite, respectively.

\section{Materials and Methods}

2.1. Constituent Soils. The soil-bentonite backfills are comprised of sand, natural clay from Nanjing city (denoted as Nanjing clay), and sodium activated calcium bentonite $(\mathrm{SACaB})$. Sand and Nanjing clay are obtained from Nanjing city, China. The Nanjing clay corresponds to a fluvial deposit. The $\mathrm{SACaB}$ is provided by MUFENF mineral processing plant in Zhenjiang City, China. Table 1 shows the basic physical properties and mineralogical compositions of the three soils used for this study. Based on the Unified Soil Classification System [14], the sand, Nanjing clay, and $\mathrm{SACaB}$ are classified as poorly graded sand (SP), lowplasticity clay $(\mathrm{CL})$, and high-plasticity clay $(\mathrm{CH})$, respectively. The result of X-ray diffraction analysis shown in Figure 1 indicates that the dominant minerals of the Nanjing clay and $\mathrm{SACaB}$ are found to be illite and montmorillonite, respectively. The basal spacing (001) of the bentonite is identified as $15.4 \AA$, indicating that the SACaB belongs to Ca-bentonite [16]. The SACaB used in this study represents typical low-quality bentonite with relatively low swell index $(S I=16.5 \mathrm{~mL} / 2 \mathrm{~g}$; see Table 1$)$; and therefore, the results could be compared with those obtained from the backfills using high-quality commercial $\mathrm{NaB}$ reported in previous studies.

2.2. Preparation of Base Mixture for Backfill. Base mixtures are prepared by mixing a predetermined mass of dry sand, Nanjing clay, and SACaB. Sand-Nanjing clay mixtures are used as representative of simulated in situ soil. The bentonite content in the base mixture $\left(B C_{\mathrm{M}}\right)$ used for SBB preparation is controlled in the range of 3.5 to $15 \%$ (dry weight basis); and it is selected to be $0 \%, 3.5 \%$, and $8 \%$ (dry weight basis) in the base mixture used for SCBB preparation. The $B C_{M}$ is calculated using equation (1). The mass ratio of sand to Nanjing clay ranges from 6 to 0.5 (dry weight basis) in the base mixture of SCBB. The symbol " $\mathrm{CB} i$ " denotes an SBB with $B C_{\mathrm{M}}$ of $i \%$ and the symbol "CBiR $j$ " denotes an SCBB with $B C_{\mathrm{M}}$ of $i \%$ and mass ratio of sand to Nanjing clay of $j$. In addition, one sand-Nanjing clay mixture is prepared for evaluating the hydraulic conductivity of typical in situ soil in the backfill. The mass ratio of sand to clay of the mixture is set at 0.5 (dry weight basis), and the mixture is denoted as R0.5. The proportion of base mixtures for all backfills tested in this study is presented in Table 2:

$$
B C_{M}=\frac{m_{\text {Ben }, M}}{m_{\text {Sand }}+m_{\text {Clay }}+m_{\text {Ben }, M}},
$$

where $m_{\text {Sand }}, m_{\text {Clay, }}$ and $m_{\mathrm{Ben}, M}$ are the mass of sand, Nanjing clay, and $\mathrm{SACaB}$ in the mixture by dry weight, respectively.

2.3. Preparation of Bentonite-Water Slurry. The bentonitewater slurry is prepared by mechanically mixing $10 \%$ dry bentonite with $90 \%$ tap water (weight basis) for $30 \mathrm{~min}$ and left for hydration for $24 \mathrm{~h}$. After hydration, the marsh funnel viscosity, density, and filtration of the prepared slurry are measured as per API 13B-1 [17], and the values are $42 \mathrm{~s}$, $1.042 \mathrm{~g} / \mathrm{cm}^{3}$, and 10.45 , respectively.

2.4. Backfill Preparation for Testing. Backfill sample for testing is prepared by mixing the base mixture with the predetermined mass of bentonite-water slurry [9]. The initial water content of backfill $\left(w_{0}\right)$ is controlled to meet the requirement of target slump $(-\Delta H)$. A $-\Delta H$ value varying from 100 to $150 \mathrm{~mm}$ is adopted to prepare backfill in the slurrytrench method for soil-bentonite cutoff wall $[1,6]$. The slump is measured according to ASTM C143 [18]. In addition, the specific gravity $\left(G_{s}\right)$ and liquid limit $\left(w_{L}\right)$ of backfills are measured as per ASTM standards $[12,13]$. It should be noted that $w_{L}$ cannot be determined using the percussion method for the simulated in situ soil (R0.5) and backfill with relatively low bentonite content and Nanjing clay content, including CB3.5, CB5, CB6, CB3.5R6, and CB3.5R4. The resulting $w_{0}$ and its corresponding $-\Delta H$, total bentonite content in backfill $(B C)$, distribution of particle sizes, $G_{s}$, and $w_{L}$ of all samples for testing are presented in Table 3. The $B C$ value is calculated using the following equation:

$$
B C=\frac{m_{\mathrm{Ben}, M}+m_{\mathrm{Ben}, S}}{m_{\mathrm{Ben}, M}+m_{\mathrm{Base}, M}+m_{\mathrm{Ben}, S}},
$$

where $m_{\mathrm{Ben}}, M$ and $m_{\mathrm{Base}}, M$ are mass of bentonite and simulated in situ soil from base mixture by dry weight, respectively, and $m_{\mathrm{Ben}, S}$ is mass of bentonite from bentonitewater slurry by dry weight. 
TABLE 1: Properties of constituted soils.

\begin{tabular}{|c|c|c|c|c|}
\hline \multirow{2}{*}{ Property } & \multirow{2}{*}{ Standard } & \multicolumn{3}{|c|}{ Constituent soil } \\
\hline & & Sand & Nanjing clay & Ca-bentonite \\
\hline Fines fraction, $F F$ & ASTM [11] & 0 & 72.5 & 100 \\
\hline Clay fraction, $C F$ & ASTM [11] & 0 & 17 & 49 \\
\hline Specific gravity, $G_{s}$ & ASTM [12] & 2.65 & 2.74 & 2.63 \\
\hline Liquid limit, $w_{L}(\%)$ & ASTM [13] & - & 34.5 & 269.4 \\
\hline Plastic limit, $w_{P}(\%)$ & ASTM [13] & - & 20.4 & 34.0 \\
\hline Classification & ASTM [14] & SP & $\mathrm{CL}$ & $\mathrm{CH}$ \\
\hline Swell index, $S I(\mathrm{~mL} / 2 \mathrm{~g})$ & ASTM [15] & - & 2.2 & 16.5 \\
\hline Primary clay mineral & 1 & - & Illite (53\%) & ${ }^{2}$ Mont. (82\%) \\
\hline
\end{tabular}

${ }^{1} \mathrm{X}$-ray diffraction analysis. ${ }^{2}$ Mont., montmorillonite.

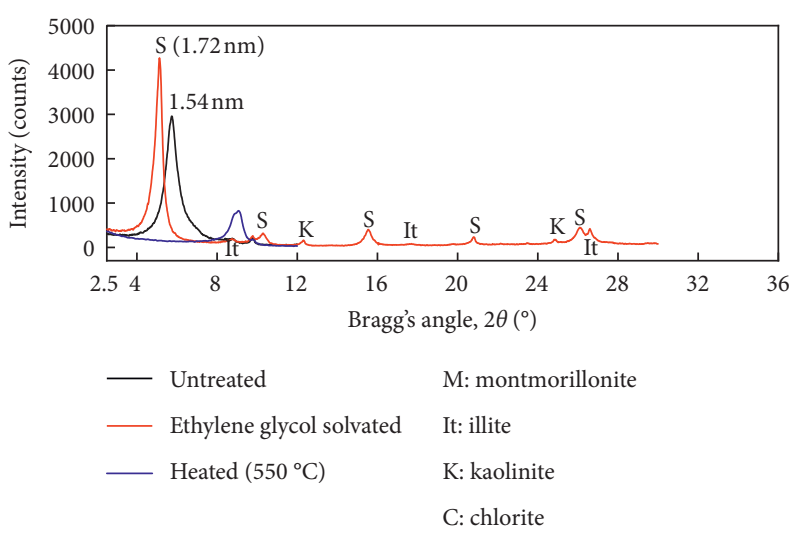

(a)

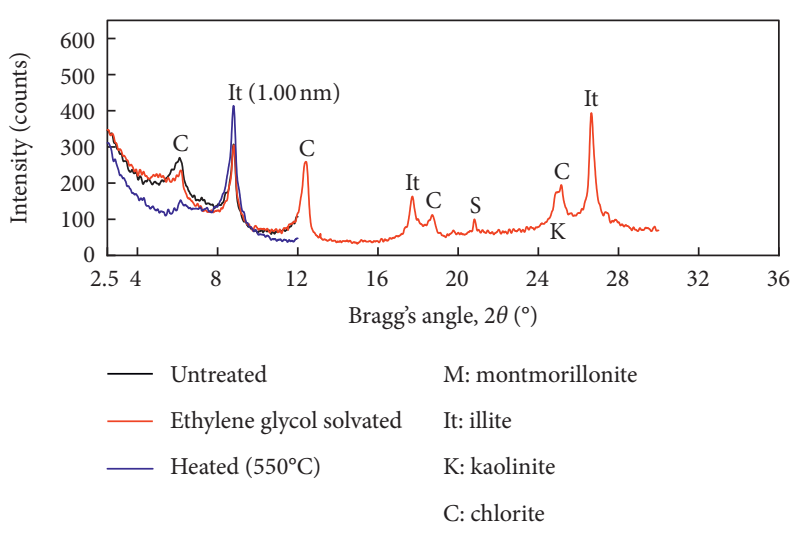

(b)

FIgUre 1: XTD plot of constituted soils: (a) SACaB and (b) Nanjing clay.

TABLE 2: Proportion of base mixtures for SB backfills.

\begin{tabular}{|c|c|c|c|c|}
\hline Sample ID & $\begin{array}{l}\text { Type of } \\
\text { backfill }\end{array}$ & $\begin{array}{l}\text { Bentonite content in base } \\
\text { mixture, } B C_{M}(\%)\end{array}$ & $\begin{array}{c}\text { Mass ratio of sand to Nanjing clay by } \\
\text { dry weight }\end{array}$ & $\begin{array}{l}\text { Nanjing clay content in base } \\
\text { mixture, } N C_{M}(\%)\end{array}$ \\
\hline CB3.5 & $\mathrm{SBB}^{1}$ & 3.5 & - & 0 \\
\hline CB5 & SBB & 5 & - & 0 \\
\hline CB6 & SBB & 6 & - & 0 \\
\hline CB8 & SBB & 8 & - & 0 \\
\hline CB10 & SBB & 10 & - & 0 \\
\hline $\mathrm{CB} 12$ & SBB & 12 & - & 0 \\
\hline CB15 & SBB & 15 & - & 0 \\
\hline CB0R0.5 & $\mathrm{SCBB}^{2}$ & 0 & 0.5 & 66.7 \\
\hline CB3.5R6 & SCBB & 3.5 & 6 & 13.8 \\
\hline CB3.5R4 & SCBB & 3.5 & 4 & 19.3 \\
\hline $\mathrm{CB} 3.5 \mathrm{R} 2$ & SCBB & 3.5 & 2 & 32.2 \\
\hline CB3.5R1 & SCBB & 3.5 & 1 & 48.3 \\
\hline CB3.5R0.5 & SCBB & 3.5 & 0.5 & 64.3 \\
\hline CB8R6 & SCBB & 8 & 6 & 13.1 \\
\hline CB8R4 & SCBB & 8 & 4 & 18.4 \\
\hline CB8R2 & SCBB & 8 & 2 & 30.7 \\
\hline CB8R1 & SCBB & 8 & 1 & 46.0 \\
\hline CB8R0.5 & SCBB & 8 & 0.5 & 61.3 \\
\hline R0.5 & - & 0 & 0.5 & 66.7 \\
\hline
\end{tabular}

${ }^{1}$ SBB: sand-bentonite backfill. ${ }^{2}$ SCBB: sand-clay-bentonite backfill.

2.5. Testing Methods. The oedometer and hydraulic conductivity tests are performed on all samples shown in Table 2. The conventional oedometer tests are conducted based on ASTM D2435 [19]. A pressure of $1 \mathrm{kPa}$ is used in the preconsolidation stage for $24 \mathrm{~h}$, and the sample is then subjected to incremental loading beginning with $3.125 \mathrm{kPa}$. 
TABLE 3: Physical properties of SB backfills tested in the study.

\begin{tabular}{|c|c|c|c|c|c|c|c|}
\hline Sample ID & $\begin{array}{c}\text { Initial water } \\
\text { content, } w_{0}(\%)\end{array}$ & $\begin{array}{c}\text { Slump, } \\
(\mathrm{mm})\end{array}$ & $\begin{array}{l}\text { Total bentonite } \\
\text { content, BC (\%) }\end{array}$ & $\begin{array}{c}\text { Fines fraction, } \\
F F^{1}(\%)\end{array}$ & $\begin{array}{l}\text { Clay size fraction, } \\
C F^{2}(\%)\end{array}$ & $\begin{array}{l}\text { Specific } \\
\text { gravity, } G_{\mathrm{s}}\end{array}$ & $\begin{array}{l}\text { Liquid limit, } \\
w_{L}(\%)\end{array}$ \\
\hline CB3.5 & 30.3 & 109 & 6.6 & 6.6 & 3.3 & 2.63 & $\mathrm{ND}^{3}$ \\
\hline CB5 & 32.6 & 120 & 8.4 & 8.4 & 4.1 & 2.64 & ND \\
\hline CB6 & 35.1 & 112 & 9.6 & 9.6 & 4.7 & 2.64 & ND \\
\hline CB8 & 40.5 & 105 & 12.1 & 12.1 & 5.9 & 2.64 & 30.6 \\
\hline CB10 & 50.1 & 118 & 14.9 & 14.9 & 7.3 & 2.64 & 34.9 \\
\hline CB12 & 60.2 & 135 & 17.5 & 17.5 & 8.6 & 2.64 & 36.3 \\
\hline CB15 & 68.6 & 110 & 21.5 & 21.5 & 10.5 & 2.64 & 41.2 \\
\hline CB0R0.5 & 31.9 & 141 & 3.5 & 50.2 & 10.3 & 2.72 & 22.0 \\
\hline CB3.5R6 & 25.5 & 114 & 6.2 & 15.9 & 5.8 & 2.66 & ND \\
\hline CB3.5R4 & 26.6 & 131 & 6.4 & 19.9 & 6.7 & 2.67 & ND \\
\hline CB3.5R2 & 25.5 & 125 & 6.2 & 28.9 & 8.0 & 2.68 & 19.0 \\
\hline CB3.5R1 & 28.8 & 124 & 6.6 & 40.4 & 10.2 & 2.70 & 21.2 \\
\hline CB3.5R0.5 & 31.9 & 116 & 6.9 & 51.9 & 12.2 & 2.72 & 24.9 \\
\hline CB8R6 & 41.1 & 120 & 12.2 & 21.3 & 9.2 & 2.66 & 27.8 \\
\hline CB8R4 & 41.8 & 123 & 12.3 & 25.0 & 10.2 & 2.66 & 27.9 \\
\hline CB8R2 & 42.6 & 114 & 12.4 & 33.5 & 11.6 & 2.68 & 28.8 \\
\hline CB8R1 & 46.5 & 129 & 12.8 & 44.4 & 13.7 & 2.69 & 29.2 \\
\hline CB8R0.5 & 46.4 & 124 & 12.7 & 54.9 & 15.5 & 2.71 & 31.0 \\
\hline R0.5 & 28.1 & 127 & 0.0 & 48.3 & 12.7 & 2.72 & ND \\
\hline
\end{tabular}

${ }^{1}$ Fines fraction, particle size $<75 \mu \mathrm{m} .{ }^{2}$ Clay size fraction, particle size $<2 \mu \mathrm{m} .{ }^{3} \mathrm{ND}$, cannot be determined.

This is done to avoid soil squeezing through the gap between the sidewall of the oedometer cell and the porous disk [20]. The loading is doubled at each incremental step until a maximum loading of $800 \mathrm{kPa}$ is reached. The duration of each loading is 24 hours.

The falling-head hydraulic conductivity test in the oedometer is used to determine the hydraulic conductivity $(k)$. The procedure of the falling-head hydraulic conductivity test in the oedometer is in accordance with Bohnhoff and Shackelford [8]. The test is conducted after the end of loading, beginning with loading of $12.5 \mathrm{kPa}$. Tap water is used as a permeant liquid. The initial hydraulic gradient is controlled to 30 . Head loss and compression deformation are measured every $8 \mathrm{~h}$ to $24 \mathrm{~h}$ during the falling-head procedure for calculating $k$ value. Permeation is continued until at least four consecutive hydraulic conductivity values are within $\pm 25 \%$ of the mean value for $k \geq 1 \times 10^{-10} \mathrm{~m} / \mathrm{s}$ or within $\pm 50 \%$ for $k<1 \times 10^{-10} \mathrm{~m} / \mathrm{s}$ according to ASTM D5084 [21].

\section{Results and Discussion}

3.1. Compressibility. Figure 2 shows the void ratio $(e)$ and the effective vertical compression stress $\left(\sigma_{v}{ }^{\prime}\right)$ compression curves on a semilogarithm scale of sand-bentonite and sandclay-bentonite backfills. The result indicates that the $e$-log $\left(\sigma_{v}{ }^{\prime}\right)$ compression curves display a significant change in slope when $\sigma_{v}{ }^{\prime}$ increases from $6.25 \mathrm{kPa}$ to $12.5 \mathrm{kPa}$. This result is more noticeable with an increase in bentonite content, as shown in Figure 2(a). Similar results are also observed in remolded natural clays, $\mathrm{NaB}$, and kaolin-bentonite mixtures $[20,22]$. The result is attributed to the existence of remolded yield stress in soil nature [23]. Thus, the compression index $\left(C_{c}\right)$ is determined from the linear portion of the $e-\log \left(\sigma_{v}{ }^{\prime}\right)$ compression curve at the postyield state in this study.

Figure 3 shows the relationship between $B C$ and $C_{c}$ of the backfills tested in this study and previous studies [4-7]. The result shows that there exists an approximately linear relationship between $B C$ and $C_{c}$ for sand-bentonite backfills with bentonites having a similar range of liquid limit. In addition, $C_{c}$ increases with an increase in bentonite liquid limit for a given $B C$. The $B C-C_{c}$ relationships of sand/SACaB backfills tested in this study and sand/ $\mathrm{NaB}$ backfills reported in previous studies [4-6] are determined using a LeastSquare-Root method; and they can be expressed by equation (3) with a coefficient of determination $\left(R^{2}\right)$ of 0.992 and 0.896 , respectively:

$$
\left\{\begin{array}{l}
C_{c}=4.95 B C-0.37\left(w_{L}=269 \%\right), \\
C_{c}=4.48 B C-0.05\left(w_{L}=488-694 \%\right) .
\end{array}\right.
$$

To understand the influence of in situ soil on $C_{c}$ of soilbentonite backfill, the relationship between natural clay content $(\mathrm{NC})$ and $C_{\mathrm{c}}$ is presented in Figure 4 . The result shows that $C_{c}$ has a tendency for increasing with an increase in $N C$ for a given range of $B C$. The $C_{c}$ value of the backfills increases linearly with increasing $N C$ and then reaches a plateau. The growth stage of the $\mathrm{NC}-\mathrm{C}_{c}$ relationship of the backfills with $B C$ of 6.2 to $6.9 \%$ and 12.1 to $12.8 \%$ can be expressed by equation (4) with R2 of 0.922 and 0.937 , respectively. In addition, it is found that the slope value of equation (3) for the $B C-C_{c}$ relationship is 16 to 23 times higher than that of equation (4) for the $N C-C_{c}$ relationship, indicating that it is $B C$ that dominates the $C_{c}$ of soil-bentonite backfill: 


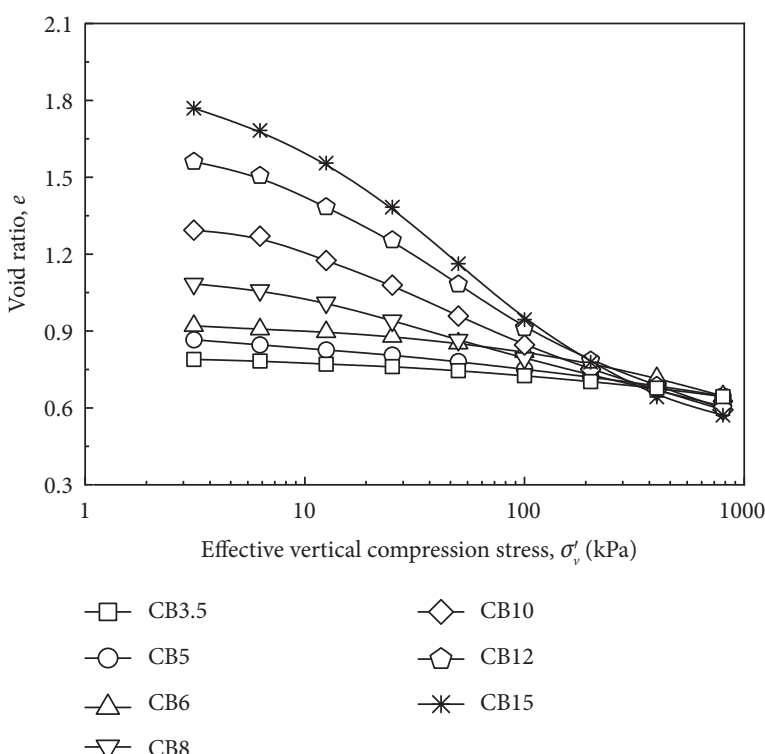

(a)

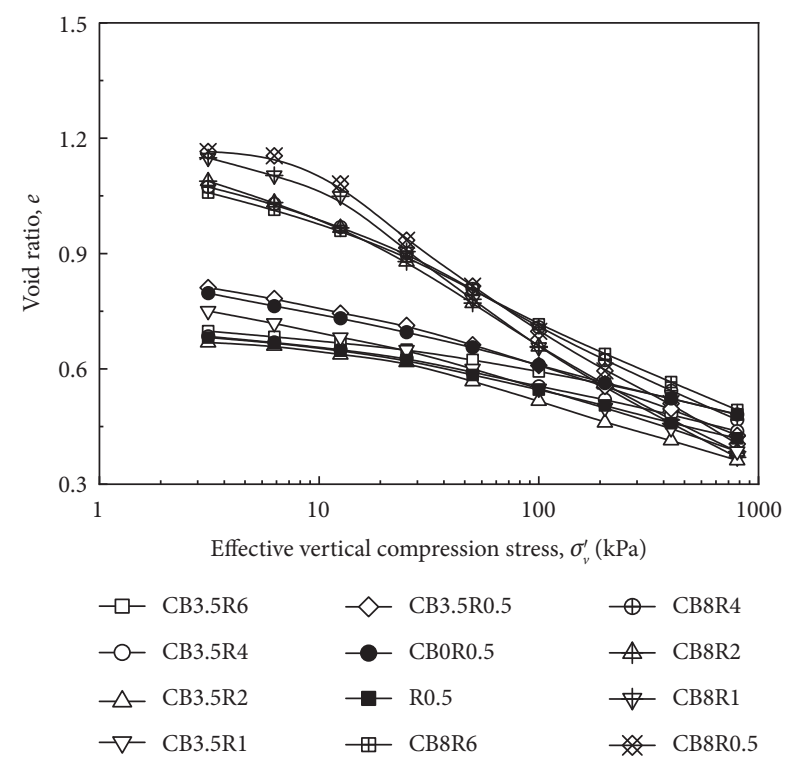

(b)

FIgURE 2: $e-\log \left(\sigma_{\mathrm{v}}{ }^{\prime}\right)$ compression curves of backfills: (a) SBB and (b) SCBB.

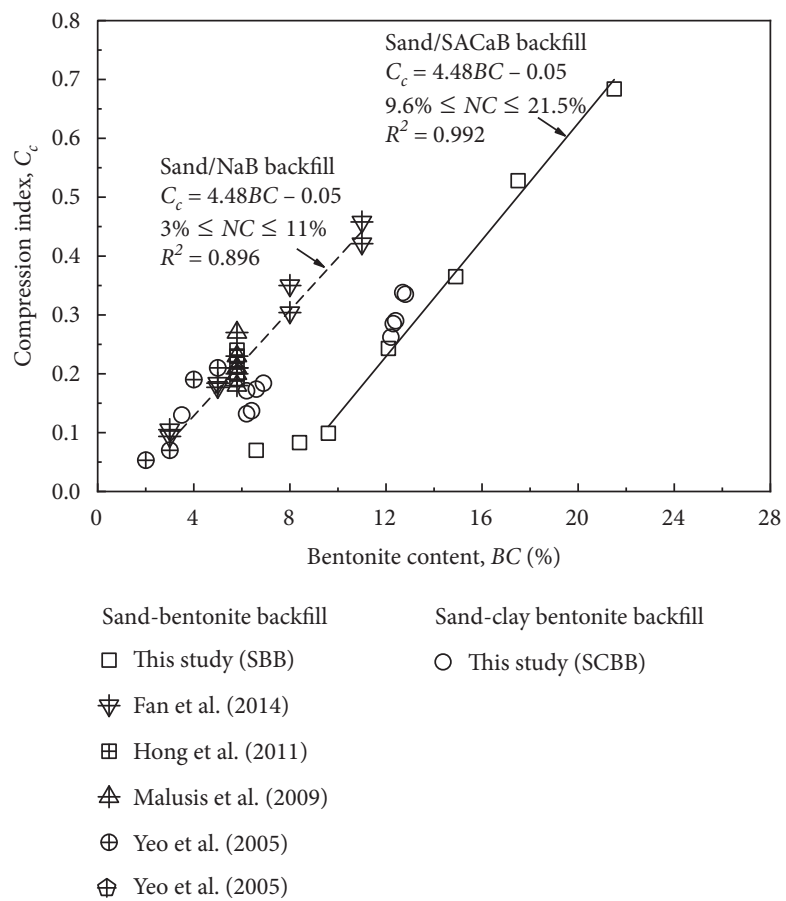

Figure 3: Relationship between bentonite content $(B C)$ and compression index $\left(C_{c}\right)$.

$$
\left\{\begin{array}{l}
C_{c}=0.308 N C+0.077\left(B C=6.1 \text { to } 6.8 \%, w_{L}=269 \%\right), \\
C_{c}=0.193 N C+0.241\left(B C=12.0 \text { to } 12.5 \%, w_{L}=269 \%\right) .
\end{array}\right.
$$

It has been understood that the compressibility of clay is affected by both soil nature and $w_{0}$, which can be described by using a function of void ratio at $\sigma_{v}{ }^{\prime}=1 \mathrm{kPa}\left(e_{1}\right)[23,24]$. Fan et al. [20] report that there exists a unique relationship between $e_{1}$ and $C_{c}$ for clay-bentonite backfills with fair bentonite content, as expressed by equation (5). Figure 5 shows the relationship between $e_{1}$ and $C_{c}$ obtained from the sand-bentonite and sand-clay-bentonite backfills. It is found that the overall trend of the $e_{1}-C_{c}$ relationship for SBB and $\mathrm{SCBB}$ is in accordance with the proposed equation (5) for clay-bentonite backfill, except for SSB with $B C$ lower than $10 \%$. The relative accuracy error of $C_{c}$ calculated using equation (5) is within $-18 \%$ to $19 \%$. This result also indicates that a sand-bentonite backfill can be regarded as a granular material when hydrated bentonite was not able to wrap 
around sand particles. Under such circumstances, the compression behavior is controlled by sand particle rearrangement through interparticle slip and rotation, and $C_{c}$ value is generally lower than 0.1 [25]. On the other hand, natural clay in simulated in situ soil contributes to filling pore spaces among sand particles that have not been filled by hydrated bentonite due to low $B C$, which avoids the formation of the skeletal structure formed by sand particles:

$$
C_{c}=0.13 e_{1}+0.056 e_{1}^{2} \text {. }
$$

3.2. Hydraulic Conductivity. Figure 6 presents the relationship between the void ratio $(e)$ and hydraulic conductivity $(k)$ on a semilogarithmic scale. The result illustrates the $e-\log (k)$ relationship is approximately linear. The $k$ values of backfills are generally lower than the recommended limit of $10^{-9} \mathrm{~m} / \mathrm{s}$ for engineered barriers, except for the $k$ of CB0R 0.5 and CB3.5 at loading increments $<100 \mathrm{kPa}$. In addition, the $k$ of the simulated in situ soil (R0.5) varies from $5.7 \times 10^{-8}$ to $1.0 \times 10^{-9} \mathrm{~m} / \mathrm{s}$, indicating that the addition of bentonite is required even for an in situ soil with a medium to high fines fraction (see Table 3).

Figure 7 presents the relationship between $B C$ and $k$ corresponding to the void ratio of 0.6 to 0.75 in this study and previous studies $[3-6,26]$. $e=0.6$ to 0.75 is chosen because the $k$ values corresponding to this range of $e$ are available from these studies, which allows for a comparison of $k$ values among the different backfills. The result illustrates that the $k$ value sharply decreases with an increase in bentonite content when $B C_{\mathrm{M}}$ is lower than $5 \%$ regardless of the bentonite quality (i.e., $\mathrm{NaB}$ or SACaB). The $k$ of SSB tested in this study decreases one order of magnitude when $B C_{\mathrm{M}}$ increases from $5 \%$ to $15 \%$, indicating that a further increase in $B C$ results in a limited decrease in $k$. Thus, $B C$ of $6.8 \%$ for the sand-bentonite backfill in this study is required in order to achieve a $k$ lower than the recommended limit of $10^{-9} \mathrm{~m} / \mathrm{s}$; while a $B C$ of 5.8 to $7.2 \%$ for the sand-bentonite backfill using conventional $\mathrm{NaB}$ results in a $k$ of $10^{-10} \mathrm{~m} / \mathrm{s}$. The difference in $k$ for a given $B C$ in Figure 7 can be attributed to the bentonite quality. The difference in hydraulic conductivity between bentonite clays can be attributed to exchangeable metals, cation exchange capacity (CEC), grain size distribution (e.g., clay size fraction), and proportion of minerals in bentonite (e.g., montmorillonite, quartz, cristobalite, and feldspar) [27-29].

To better understand the effect of in situ soil on the hydraulic conductivity of the backfill, the relationship between incremental clay size fraction due to addition of natural clay $(\triangle C F)$ and $k$ corresponding to void ratio of 0.6 to 0.75 is presented in Figure 8. The result indicates that the impact of in situ soil on hydraulic conductivity depends on $B C$. The $k$ would show a significant decrease with increasing $\triangle C F$ from the simulated in situ soil when the backfill contains a relatively low amount of bentonite; while $k$ is unlikely to be affected by $\triangle C F$ from the simulated in situ soil for the backfill with relatively high $B C$. $k$ of the backfill with $B C_{M}$ of $3.5 \%$ (i.e., $B C=6.2$ to $6.9 \%$ ) is approximately one order of magnitude when the clay fraction increases from

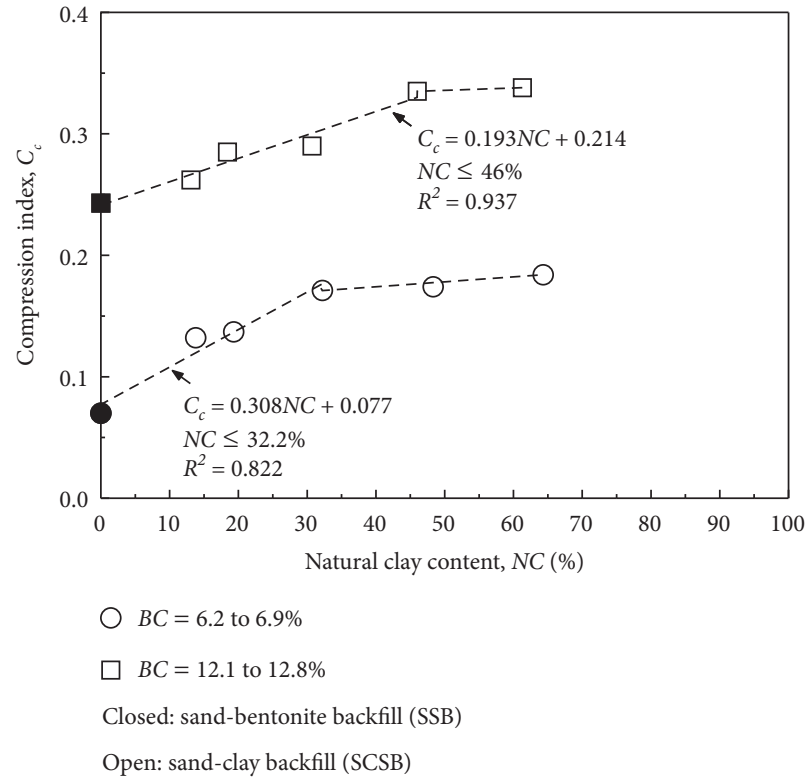

FIgURE 4: Relationship between natural clay content (NC) and compression index $\left(C_{c}\right)$.

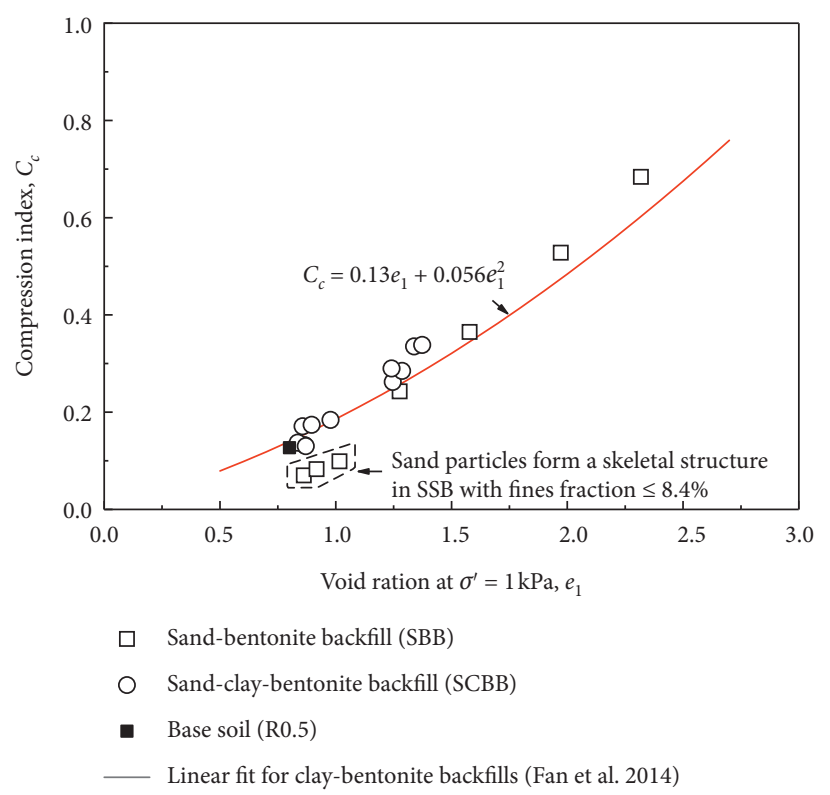

FIgURE 5: Relationship between void ratio at $\sigma_{v}{ }^{\prime}=1 \mathrm{kPa}\left(e_{1}\right)$ and compression index $\left(C_{c}\right)$.

3.3\% (CB3.5) to $13.9 \%$ (CB3.5R0.5). In contrast, a minimal decrease in $k$ is found regardless of increment in $C F$ from the simulated in situ soil for the backfills with $B C_{M}$ of $8 \%$ (i.e., $B C=12.2$ to $12.8 \%)$.

3.3. Estimating $k$ of Sand-Bentonite Blends Using Void Ratio of Bentonite. Kenney et al. [30] develop a characteristic parameter, void ratio of bentonite $\left(e_{b}\right)$, to predict $k$ of the saturated compacted sand-bentonite mixtures. The basic assumption of $e_{b}$ is that sand-bentonite mixture is regarded as an ideal homogeneous mixture, in which sand particle is 


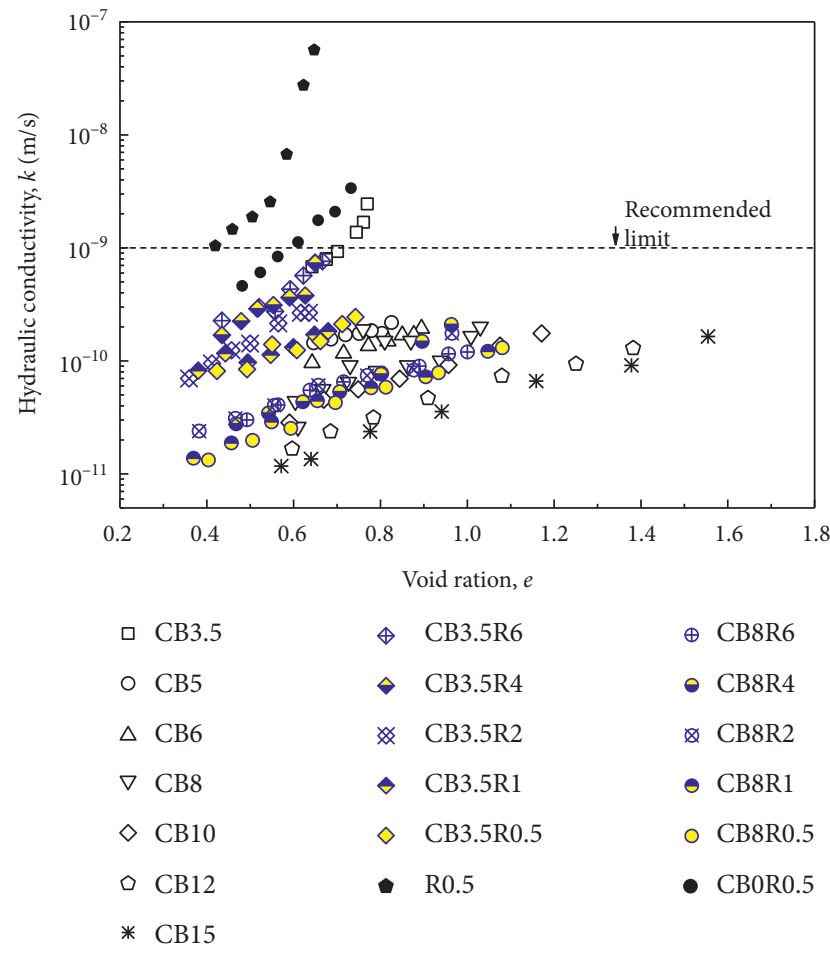

FIGURE 6: Relationship between void ratio $(e)$ and measured hydraulic conductivity $(k)$.

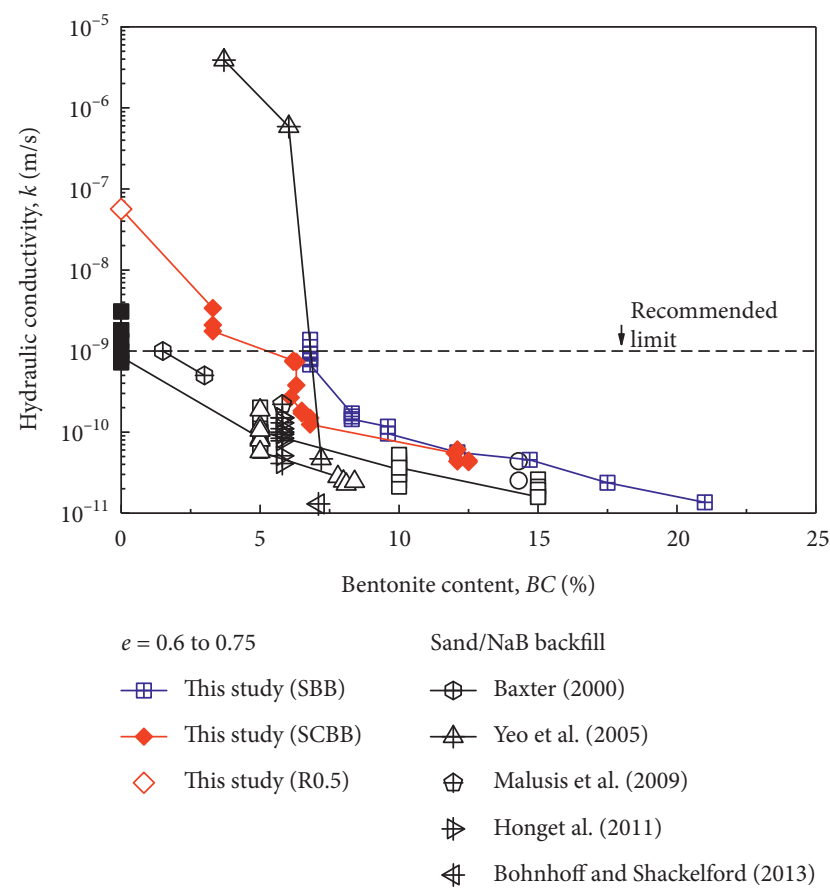

Figure 7: Relationship between total bentonite content $(B C)$ and hydraulic conductivity $(k)$.

impermeable, and seepage only exists in hydrated bentonite paste. The proposed $e_{\mathrm{b}}$ is defined as the ratio of volume of void space to volume of bentonite, which can be expressed by equation (6) or the sand-bentonite mixtures:

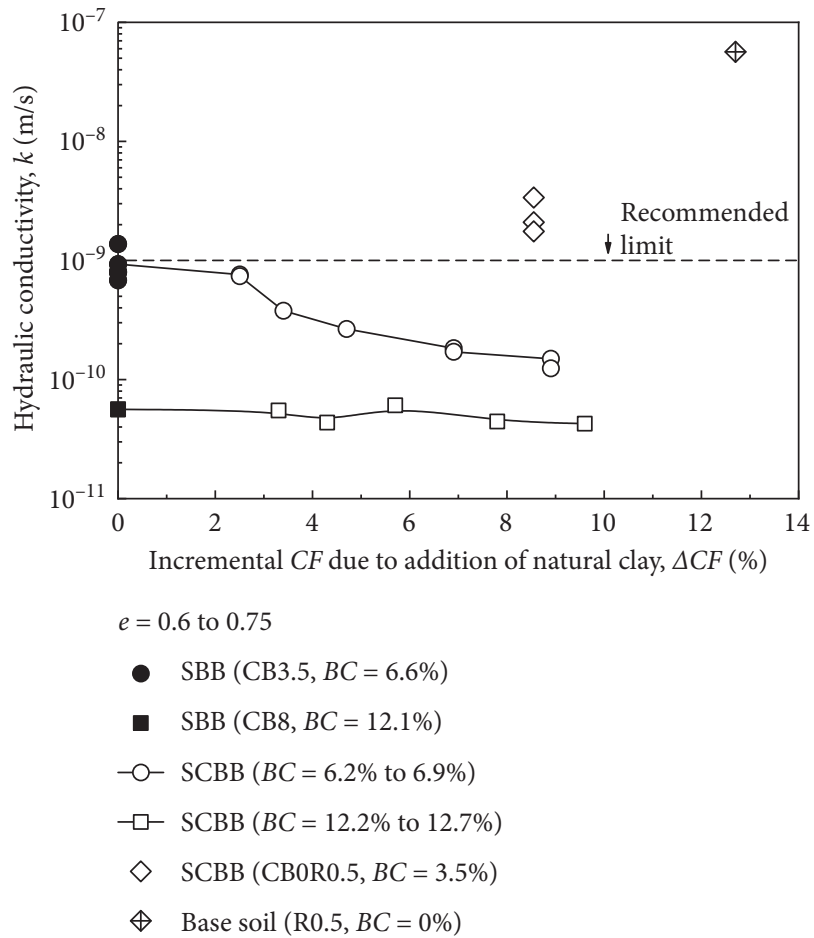

Figure 8: Relationship between incremental CF due to the addition of natural clay and hydraulic conductivity $(k)$.

$$
e_{b}=\frac{V_{w}}{V_{\text {Ben }}}=G_{s, \text { Ben }}\left[\frac{\rho_{w}}{B C \cdot \rho_{d, M}}-\frac{1-B C}{G_{s, \text { Sand }}}\right]-1,
$$

where $V_{w}$ and $V_{\text {Ben }}$ are the volume of pore water and bentonite, respectively; $G_{s, \text { Ben }}, G_{s, \text { Sand }}$, and $G_{s, \mathrm{M}}$ are the specific gravity of bentonite, sand, and sand-bentonite mixture, respectively; $B C$ is the bentonite content; $\rho_{w}$ is the density of pore water; and $\rho_{d, M}$ is the dry density of the mixture.

Figure 9 presents the relationship between $e_{b}$ and $k$ of sand-bentonite blends in this study and previous studies $[4,6,7,30-33]$ on a logarithmic scale. The maximum $e_{b}$ value in this study is 11.3 while those of sand/NaB backfills reported in previous studies $[4,6,7]$ vary from 19.5 to 30.6 .

The result illustrates that the $e_{b}-k$ relationship of sandbentonite blends under various testing conditions (e.g., sample preparation, bentonite quality, and bentonite content) generally possess a universal overall trend. The overall trend for the $e_{b^{-}} k$ relationship determined using a LeastSquare-Root method is expressed by equation (7) with $R^{2}$ of merely 0.16 , and a more accurate description of the $e_{b}-k$ relationship corresponding to $e_{b}$ ranging from 1 to $66.7 \mathrm{can}$ be expressed by equation (8) using a Least-Square-Root method with $R^{2}$ of 0.816 . In fact, a rational $e_{b}-k$ relationship shall be developed based on an ideal sand-bentonite mixture, in which the $e_{b}$ value shall be no more than the free-swell void ratio of the bentonite $\left(e_{b, f-s}\right)$ [30]. Based on that, Castelbaum and Shackelford [32] indicated that a sandbentonite mixture with $e_{b}$ value lower than approximately 1.4 times its corresponding $e_{b, f-s}$ can be expected for ideal 


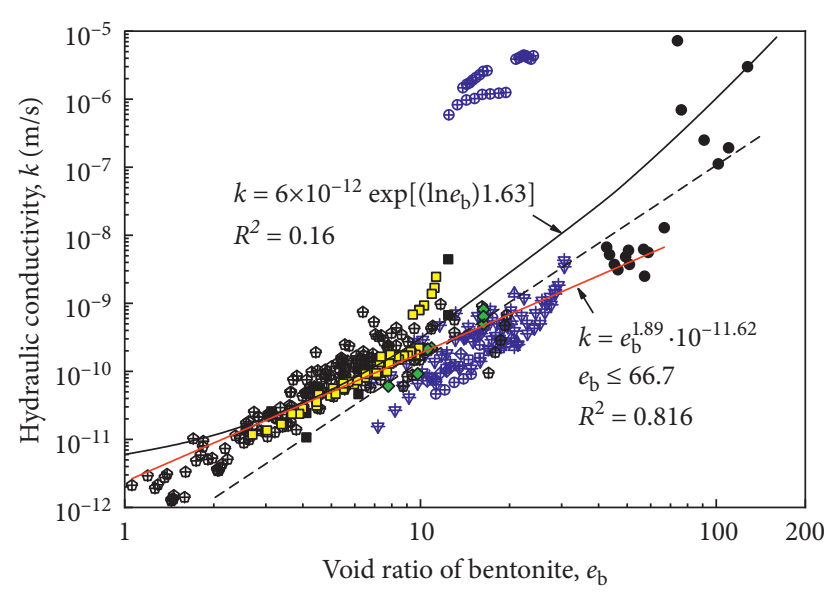

Sand -bentonite backfill Compacted sand-bentonite

- This study (SBB)

* Fan et al. (2014)

Bohnhoff and

Shackelford (2013)

田 Hong et al. (2011)

4 Malusis et al. (2009)

$\oplus$ Yeo et al. (2005)

Sand -bentonite mixture

- Castelbaum and

- Shackelford (2009)

由 Sivapullaiah et al. (2000)

FIGURE 9: Relationship between void ratio of bentonite $\left(e_{b}\right)$ and hydraulic conductivity $(k)$ of sandy soil-bentonite blends in this study and previous studies.

mixtures; otherwise, it shall be considered as a nonideal mixture. The $e_{b}-k$ relationship obtained from sand-bentonite backfills in this study is generally consistent with equation (8) except for the CB3.5 sample. One possible reason might be a side-leakage during the hydraulic conductivity test.

Only the results reported by Yeo et al. [4] show a significant deviation from the overall trend for the $e_{b}-k$ relationship, which might be due to the fact that the amount of hydrated bentonite $\left(B C_{M}<5 \%\right)$ is insufficient to fully cover sand particles, resulting in seepage among sand particles:

$$
\begin{aligned}
& k=6.0 \times 10^{-12} \exp \left[\left(\ln e_{b}\right)^{1.63}\right], \\
& k=e_{b}^{1.89} \cdot 10^{-11.62}\left(e_{b}<66.7\right) .
\end{aligned}
$$

Considering that the $e_{b}$ value for sand-bentonite backfills is generally lower than 3 , equation (8) can be used to predict the $k$ value of sand-bentonite backfills. However, it should be noticed that in situ soil used for soil-bentonite backfill is not pure sand in practice. As a result, equation (8) is not suitable for predicting a $k$ of soil-bentonite backfill in real condition.

3.4. Proposed Method for Predicting $k$ of Soil-Bentonite Backfills. A large number of methods have been developed for predicting the hydraulic conductivity of clays and clay- bentonite backfills, in which $w_{L}$ is an integral index property for representing swell potential and mineralogical composition of soil $[19,29]$. However, $w_{L}$ of sand-based soilbentonite backfill could be questionable especially for backfills with relatively low bentonite content (see Table 3 ).

In this study, a new characteristic parameter, named the apparent void ratio of clay size fraction in soil-bentonite backfill $\left(e_{C}\right)$, is developed for predicting $k$ of soil-bentonite backfills on account of the fact that the hydraulic conductivity of natural clays and bentonite clays is significantly affected by liquid limit and soil nature of clay-sized minerals. The concept of $e_{C}$ originates from the void ratio of bentonite proposed by Kenney et al. [30]. For soil-bentonite backfill with clayey soil in in situ soil, the backfill herein is simplified as an ideal, three-constituent, saturated homogeneous mixture of sand $(4.75 \mathrm{~mm}$ to $75 \mu \mathrm{m})$, silt and clay $(<75 \mu \mathrm{m})$, and bentonite (hereinafter referred to as ideal mixture). Base on the concept of $e_{b}$, it is assumed that all water seepages through silt and clay from the in situ soil and hydrated bentonite whereas sand particles themselves are impermeable. In addition, the $k$ of the ideal mixture would be controlled by the hydraulic conductivity of the clay size fraction $(<2 \mu \mathrm{m})$ in bentonite and in situ soil. Moreover, an empirical coefficient is used to reflect the difference in swell potential between silt and clay from the in situ soil and hydrated bentonite. Hence, $e_{C}$ is defined by equation (9) and the method for calculating the $e_{C}$ value is given by equation (10):

$$
\begin{aligned}
& e_{C}=\frac{V_{w}}{\alpha \cdot V_{\mathrm{IS}}^{C}+V_{\mathrm{Ben}}^{C}}, \\
& e_{\mathrm{C}}=\frac{w}{L L R(1-B C) \cdot C F_{\mathrm{IS}} / G_{\mathrm{s}, \mathrm{IS}}+B C \cdot C F_{\mathrm{Ben}} / G_{\mathrm{s}, \mathrm{Ben}}},
\end{aligned}
$$

where $V_{I S}^{C}$ and $V_{B e n}^{C}$ are the volume of clay size fraction in in situ soil and bentonite, respectively; $V_{w}$ is the volume of water; parameter $\alpha$ is an empirical coefficient reflecting the correlation of swell potential between in situ soil and bentonite; $w$ is the backfill water content; $C F_{\mathrm{IS}}$ and $C F_{\mathrm{Ben}}$ are clay size fraction in in situ soil and bentonite, respectively; $G_{s}$, Is is the specific gravity of portion of in situ soil that passes the $425 \mu \mathrm{m}$ sieve; $G_{\mathrm{s}}$, Ben is the specific gravity of bentonite; $L L R$ is the apparent liquid limit ratio, which is obtained from the liquid limit of portion of in situ soil that passes the $425 \mu \mathrm{m}$ sieve and bentonite; and $B C$ is bentonite content in the backfill, which is available from construction report. A special case in equation (10) is that $e_{C}=e_{b}$ when $C F_{\mathrm{IS}}=0$ and $C F_{\mathrm{Ben}}=100 \%$. In fact, $e_{\mathrm{C}}$ represents the void ratio that dominates the flow seepage in soil-bentonite backfill, which includes not only the void ratio of bentonite but the void ratio of clay fraction of natural clay in the backfill.

Figure 10 presents the relationship between $e_{\mathrm{C}}$ and $k$ of the soil-bentonite backfills in this study on a semilog scale. The result indicates that the $e_{C}-\log (k)$ relationship for all backfills generally shows a unique linear. The $e_{C}-\log (k)$ relationship determined using a Least-Square-Root method is expressed by equation (11) with $R^{2}$ value of 0.856 . To obtain better goodness of fit, a regression analysis of the $e_{C}-\log (k)$ 


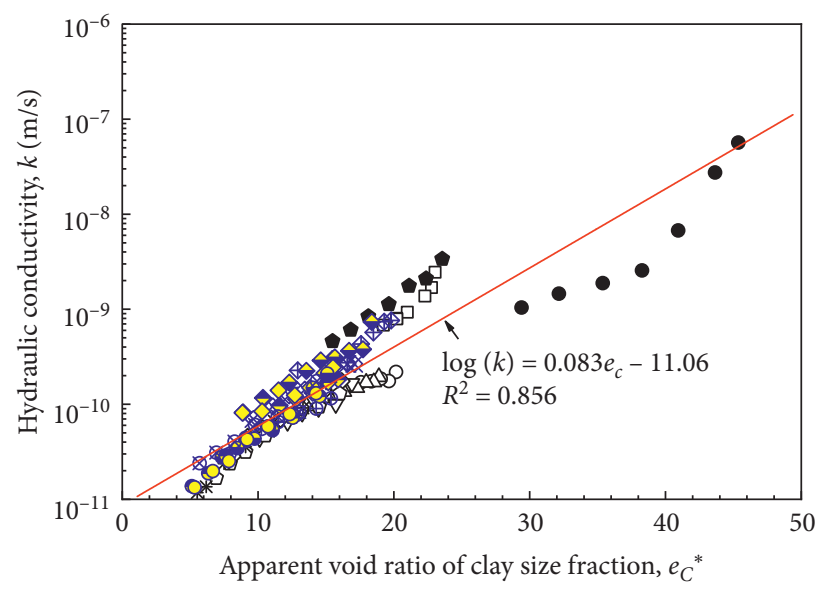

$\begin{array}{lll}\bullet \mathrm{CB} 3.5 & \diamond \mathrm{CB} 3.5 \mathrm{R} 6 & \oplus \mathrm{CB} 8 \mathrm{R} 6 \\ \circ \mathrm{CB} 5 & \diamond \mathrm{CB} 3.5 \mathrm{R} 4 & \bullet \mathrm{CB} 8 \mathrm{R} 4 \\ \triangle \mathrm{CB} 6 & \rtimes \mathrm{CB} 3.5 \mathrm{R} 2 & \oplus \mathrm{CB} 8 \mathrm{R} 2 \\ \nabla \mathrm{CB} 8 & \diamond \mathrm{CB} 3.5 \mathrm{R} 1 & \bullet \mathrm{CB} 8 \mathrm{R} 1 \\ \diamond \mathrm{CB} 10 & \diamond \mathrm{CB} 3.5 \mathrm{R} 0.5 & \circ \mathrm{CB} 8 \mathrm{R} 0.5 \\ \diamond \mathrm{CB} 12 & \bullet \mathrm{R} 0.5 & \bullet \mathrm{CB} 0 \mathrm{R} 0.5 \\ * \mathrm{CB} 15 & - \text { Linear fit } & \end{array}$

FIGURE 10: Relationship between apparent void ratio of clay size fraction $\left(e_{C}\right)$ and hydraulic conductivity $(k)$.
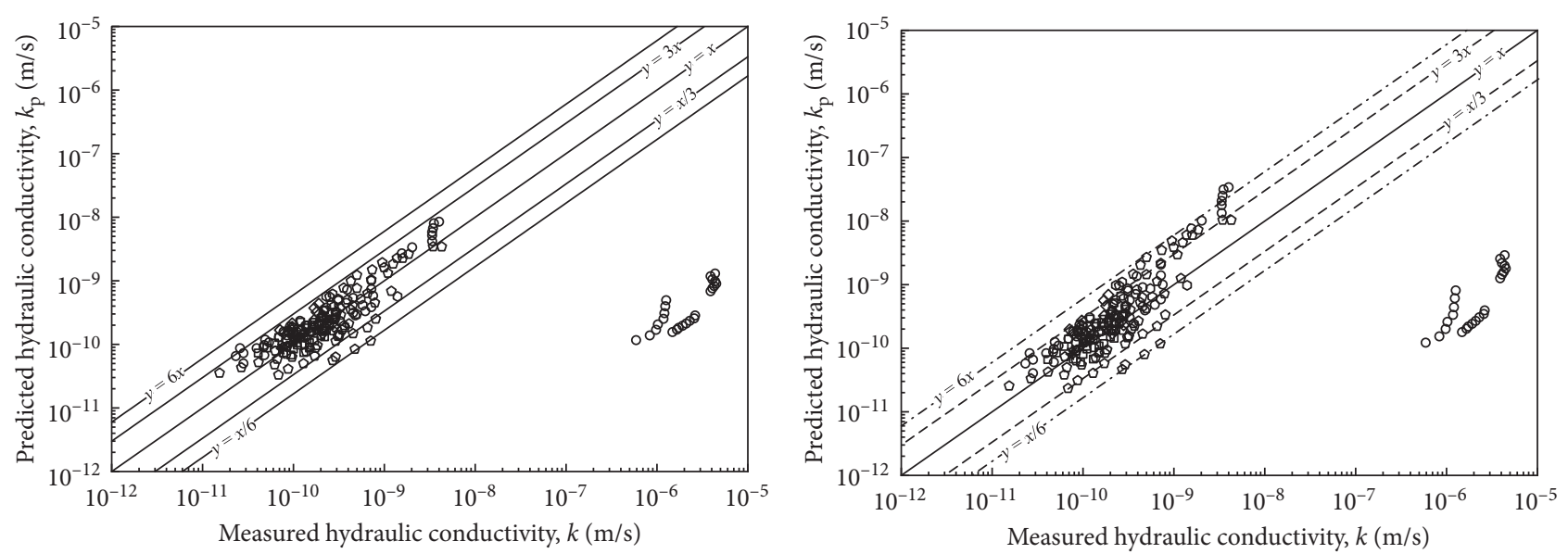

$\begin{array}{ll}\begin{array}{l}\text { Sand-bentonite backfill } \\ \text { with amendment }\end{array} & \text { Sand-bentonite backfill } \\ \text { ¿ Hong et al. (2011) } & \text { ○ Fan et al. (2014) } \\ \diamond \text { Malusis et al. (2011) } & \text { Bohnhoff and } \\ \text { Shackelford (2013) } \\ \text { Sand-clay backfill } & \text { ○ Malusis and } \\ \text { ○ Yeo et al. (2005) } & \text { McKeehan (2013) }\end{array}$

(a)

$\begin{array}{ll}\begin{array}{l}\text { Sand-bentonite backfill } \\ \text { with amendment }\end{array} & \text { Sand-bentonite backfill } \\ \text { ○ Hong et al. (2011) } & \text { ○ Fan et al. (2014) } \\ \diamond \text { Malusis et al. (2011) } & \text { * Bohnhoff and } \\ \text { Shackelford (2013) } \\ \begin{array}{l}\text { Sand-clay backfill } \\ \text { ○ Yeo et al. (2005) }\end{array} & \text { ○alusis and } \\ \end{array}$

(b)

FIGURE 11: Predicted versus measured hydraulic conductivity values: (a) $k$ predicted using equation (11) and (b) $k$ predicted using equation (12). 
TABLE 4: Result of mean $(\mu)$, standard deviation $(S D)$, and ranking distance $(R D)$ of the set of $k_{\mathrm{p}} / k$.

\begin{tabular}{lccc}
\hline Equation & Mean $(\mu)$ & Standard deviation $(S D)$ & Ranking distance $(R D)$ \\
\hline Equation (11) & 1.092 & 0.691 & 0.697 \\
Equation (12) & 1.619 & 1.473 & 1.598 \\
\hline
\end{tabular}

relationship with $e_{\mathrm{C}}$ lower than 24 gives equation (12) with a $R^{2}$ value of 0.866 :

$$
\begin{aligned}
& \log (k)=0.083 e_{C}-11.06, \\
& \log (k)=0.109 e_{C}-11.39\left(e_{C} \leq 24\right) .
\end{aligned}
$$

The predictive capacity of equation (11) for soil-bentonite backfills is evaluated by using published data from sand-bentonite backfill with amendments $[5,6]$, sand-clay backfill [4], and sand/NaB backfill [7, 26, 34]. The predictive capacity is evaluated using the ratio of measured hydraulic conductivity to predicted hydraulic conductivity $\left(k_{p} / k\right)$, and the mean $(\mu)$, standard deviation $(S D)$, and ranking distance $(R D)$ of the set of $k_{\mathrm{p}} / k$ [35]. The $\mu$ and $S D$ of the set of $k_{p} / k$ are used to indicate the accuracy and precision (i.e., the amount of dispersion), respectively. A predictive equation possesses a better predictive capacity when the $\mu$ value is closer to 1 and the $S D$ value is closer to 0 . The $R D$ value, which gives equal weight to accuracy and precision, is proposed for comparing the predictive capacity of different empirical equations in previous studies [36]. The $R D$ value is given by the following equation:

$$
\mathrm{RD}=\sqrt{(1-\mu)^{2}+S D^{2}}
$$

The result indicates that although equation (12) has a slightly higher $R^{2}$ value than that of equation (11), equation (11) shows a better predictive capacity of $k$ for sand-bentonite backfills with amendment, sand-clay backfills, and sand-bentonite backfills reported in previous studies, as presented in Figure 11. The resulting predictive capacities of equations (11) and (12), including the $\mu, S D$, and $R D$ values of the set of $k_{p} / k$, are presented in Table 4. Regarding equation (11), the $\mu$ and $R D$ value is closer to 1 and the $S D$ is closer to 0 , indicating that equation (11) is better than equation (12). In addition, the $k$ value predicted using equation (11) generally falls in the range of $1 / 6$ to 6 times the measured $k$ values (data size $=285$ ); and $85 \%$ of the ratio of $k_{p}$ to $k$ is within $1 / 3$ to 3 . This indicates that a prediction of $k$ of in situ soil-bentonite backfill using equation (11) is rational [29].

Both characteristic parameters $e_{b}$ and $e_{C}$ are developed from the ideal homogeneous mixture, in which sand particle is considered as impermeable material. However, equation (11) is suitable for various types of soil-bentonite backfills, in which in situ soil consists of sand, silt, and clay with various proportions whereas equation (8) could only be used under the condition of pure sand-bentonite backfill. Moreover, all index properties used for $e_{C}$ calculation are available from conventional lab tests.

\section{Conclusions}

This study investigates the soil-bentonite backfills that are prepared using sand, natural clay, and a typical commercial sodium activated calcium bentonite. Sand-natural clay mixtures with various proportions are used to simulate excavated in situ soils. The compressibility and hydraulic conductivity are evaluated via a series of oedometer tests and falling-head hydraulic conductivity test in the oedometer. The following conclusions can be drawn:

(1) The impact of in situ soil on the compressibility of soil-bentonite backfills is relatively limited compared with bentonite content. The result of this study shows that the compression index tends to increase linearly with increased natural clay content and then reaches a plateau for a given range of bentonite content. There exists a unique relationship between void ratio at $\sigma_{\mathrm{v}}{ }^{\prime}=1 \mathrm{kPa}\left(e_{1}\right)$ and compression index for soil-bentonite backfills containing various in situ soil and bentonite: $C_{\mathrm{c}}=0.13 e_{1}+0.056 e_{1}^{2}$.

(2) The hydraulic conductivity $(k)$ of the backfills tested in this study is lower than the recommended limit of $10^{-9} \mathrm{~m} / \mathrm{s}$, except for two backfills containing a low amount of bentonite and natural clay (CBOR6 and CB3.5 sample). Bentonite content is the dominant factor in the $k$ value. However, the impact of in situ soil on the $k$ value is considerable for backfill with a relatively low bentonite content (e.g., $B C=6.2 \%$ to $6.9 \%)$.

(3) The void ratio of bentonite provides an effective method for predicting $k$ of pure sand-bentonite mixtures. A newly proposed method is applied to predict the $k$ values for soil-bentonite backfills containing various in situ soil and bentonite: $\log (k)=0.083 e_{C}-11.06$. The characteristic parameter $e_{\mathrm{C}}$, named the apparent void ratio of clay size fraction, in the predictive equation represents the void ratio that dominates the flow seepage in soilbentonite backfill. The predictive capacity of the proposed method is examined by using independent experimental data from this study. The result shows that the predicted $k$ values are generally consistent with the measured $k$ value. $85 \%$ of the predicted $k$ values fall in the range of $1 / 3$ to 3 times those measured $k$ values.

\section{Data Availability}

The data used to support the findings of this study are available from the corresponding author upon request. 


\section{Conflicts of Interest}

The authors declare that they have no conflicts of interest.

\section{Acknowledgments}

The authors are grateful for the financial support of the National Key Research and Development Program (2018YFC1803100), the National Natural Science Foundation of China (51908121 and 41877248), the Natural Science Foundation of Jiangsu Province (BE2017715), the China Postdoctoral Science Foundation Grant (2018M642143), and the Fundamental Research Funds for the Central Universities (2242019R20033).

\section{References}

[1] Y.-L. Yang, K. R. Reddy, Y.-J. Du, and R.-D. Fan, "Sodium hexametaphosphate (SHMP)-amended calcium bentonite for slurry trench cutoff walls: workability and microstructure characteristics," Canadian Geotechnical Journal, vol. 55, no. 4, pp. 528-537, 2018.

[2] T. Zhang, Y.-L. Yang, and S.-Y. Liu, "Application of biomass by-product lignin stabilized soils as sustainable geomaterials: a review," Science of The Total Environment, vol. 89, no. 138830, 2020.

[3] D. Y. Baxter, Mechanical behavior of soil-bentonite cutoff walls, Ph.D. Thesis, Civil Engineering, Virginia Polytechnic Institute and State University, Blacksburg, VI, USA, 2000.

[4] S.-S. Yeo, C. D. Shackelford, and J. C. Evans, "Consolidation and hydraulic conductivity of nine model soil-bentonite backfills," Journal of Geotechnical and Geoenvironmental Engineering, vol. 131, no. 10, pp. 1189-1198, 2005.

[5] M. A. Malusis, E. J. Barben, and J. C. Evans, "Hydraulic conductivity and compressibility of soil-bentonite backfill amended with activated carbon," Journal of Geotechnical and Geoenvironmental Engineering, vol. 135, no. 5, pp. 664-672, 2009.

[6] C. S. Hong, C. D. Shackelford, and M. A. Malusis, "Consolidation and hydraulic conductivity of zeolite amended soilbentonite backfills," Journal of Geotechnical and Geoenvironmental Engineering, vol. 138, no. 1, pp. 15-25, 2011.

[7] R. D. Fan, Y. J. Du, S. Y. Liu et al., "Compressibility and hydraulic conductivity of sand/clay-bentonite backfills," in Proceedings of the Geo-Shanghai 2014, Shanghai, China, May 2014.

[8] G. L. Bohnhoff and C. D. Shackelford, "Hydraulic conductivity of polymerized bentonite-amended Backfills," Journal of Geotechnical and Geoenvironmental Engineering, vol. 140, no. 3, Article ID 04013028, 2014.

[9] Y. J. Du, R. D. Fan, S. Y. Liu, K. R. Reddy, and F. Jin, "Workability, compressibility and hydraulic conductivity of zeolite-amended clayey soil/calcium-bentonite backfills for slurry-trench cutoff walls," Engineering Geology, vol. 195, pp. 258-268, 2015.

[10] J. C. Evans and H. Huang, "Hydraulic conductivity of soil bentonite slurry walls," in Proceedings of the Geo-Chicago 2016, Chicago, IL, USA, August 2016.

[11] ASTM, Standard Test Method for Particle-Size Distribution (Gradation) of Fine-Grained Soils Using the Sedimentation (Hydrometer) Analysis, ASTM, West Conshohocken, PA, USA, 2017.
[12] ASTM, Standard Test Methods for Specific Gravity of Soil Solids by Water Pycnometer, ASTM, West Conshohocken, PA, USA, 2014.

[13] ASTM, Standard Test Methods for Liquid Limit, Plastic Limit, and Plasticity Index of Soils, ASTM, West Conshohocken, PA, USA, 2017.

[14] ASTM, Standard Practice for Classification of Soils for Engineering Purposes (Unified Soil Classification System), ASTM, West Conshohocken, PA, USA, 2017.

[15] ASTM, Standard Test Method for Swell Index of Clay Mineral Component of Geosynthetic Clay Liners, ASTM, West Conshohocken, PA, USA, 2018.

[16] M. Ç. Karakaya, N. Karakaya, and S. Bakır, "Some properties and potential applications of the $\mathrm{Na}$ - and Ca-bentonites of ordu (N.E. Turkey)," Applied Clay Science, vol. 54, no. 2, pp. 159-165, 2011.

[17] API, Recommended Practice for Field Testing Water-Based Drilling Fluids, American Petroleum Institute, Washington, DC, USA, 2009.

[18] ASTM, Standard Test Method for Slump of Hydraulic-Cement Concrete, ASTM, West Conshohocken, PA, USA, 2020.

[19] ASTM, Standard Test Methods for One-Dimensional Consolidation Properties of Soils Using Incremental Loading, ASTM, West Conshohocken, PA, USA, 2004.

[20] R.-D. Fan, Y. J. Du, K. R. Reddy, S. Y. Liu, and Y. L. Yang, "Compressibility and hydraulic conductivity of clayey soil mixed with calcium bentonite for slurry wall backfill: initial assessment," Applied Clay Science, vol. 101, pp. 119-127, 2014.

[21] ASTM, Standard Test Methods for Measurement of Hydraulic Conductivity of Saturated Porous Materials Using a Flexible Wall Permeameter, ASTM, West Conshohocken, PA, USA, 2016.

[22] V. Sreedharan and S. Puvvadi, "Compressibility behaviour of bentonite and organically modified bentonite slurry," Géotechnique, vol. 63, no. 10, pp. 876-879, 2013.

[23] Z.-S. Hong, J. Yin, and Y.-J. Cui, "Compression behaviour of reconstituted soils at high initial water contents," Géotechnique, vol. 60, no. 9, pp. 691-700, 2010.

[24] L.-L. Zeng, Z.-S. Hong, and Y.-J. Cui, "Determining the virgin compression lines of reconstituted clays at different initial water contents," Canadian Geotechnical Journal, vol. 52, no. 9, pp. 1408-1415, 2015.

[25] G. Mesri and B. Vardhanabhuti, "Compression of granular materials," Canadian Geotechnical Journal, vol. 46, no. 4, pp. 369-392, 2009.

[26] G. L. Bohnhoff and C. D. Shackelford, "Consolidation behavior of polymerized bentonite-amended backfills," Journal of Geotechnical and Geoenvironmental Engineering, vol. 140, no. 5, Article ID 04013055, 2013.

[27] M. H. Gleason, D. E. Daniel, and G. R. Eykholt, "Calcium and sodium bentonite for hydraulic containment applications," Journal of Geotechnical and Geoenvironmental Engineering, vol. 123, no. 5, pp. 438-445, 1997.

[28] H. Komine, "Predicting hydraulic conductivity of sandbentonite mixture backfill before and after swelling deformation for underground disposal of radioactive wastes," Engineering Geology, vol. 114, no. 3-4, pp. 123-134, 2010.

[29] R. P. Chapuis, "Predicting the saturated hydraulic conductivity of soils: a review," Bulletin of Engineering Geology and the Environment, vol. 71, no. 3, pp. 401-434, 2012.

[30] T. C. Kenney, W. A. V. Veen, M. A. Swallow, and M. A. Sungaila, "Hydraulic conductivity of compacted bentonite-sand mixtures," Canadian Geotechnical Journal, vol. 29, no. 3, pp. 364-374, 1992. 
[31] P. V. Sivapullaiah, A. Sridharan, and V. K. Stalin, "Hydraulic conductivity of bentonite-sand mixtures," Canadian Geotechnical Journal, vol. 37, no. 2, pp. 406-413, 2000.

[32] D. Castelbaum and C. D. Shackelford, "Hydraulic conductivity of bentonite slurry mixed sands," Journal of Geotechnical and Geoenvironmental Engineering, vol. 135, no. 12, pp. 1941-1956, 2009.

[33] K. K. Tripathi and B. V. S. Viswanadham, "Evaluation of the permeability behaviour of sand-bentonite mixtures through laboratory tests," Indian Geotechnical Journal, vol. 42, no. 4, pp. 267-277, 2012.

[34] M. A. Malusis and M. D. McKeehan, "Chemical compatibility of model soil-bentonite backfill containing multiswellable bentonite," Journal of Geotechnical and Geoenvironmental Engineering, vol. 139, no. 2, pp. 189-198, 2013.

[35] T. L. Orr and C. Cherubini, "Use of the ranking distance as an index for assessing the accuracy and precision of equations for the bearing capacity of piles and at-rest earth pressure coefficient," Canadian Geotechnical Journal, vol. 40, no. 6, pp. 1200-1207, 2003.

[36] H. Güllü, H. Canakci, and A. Alhashemy, "Use of ranking measure for performance assessment of correlations for the compression index," European Journal of Environmental and Civil Engineering, vol. 22, no. 5, pp. 578-595, 2018. 